\section{Sound in Renaissance Science}

Carlos Gutiérrez Cajaraville

Research Project: "La obra musical renacentista: fundamentos, repertorios y prácticas" HAR

2015-70181-P, University of Valladolid, Valladolid, Spain

\section{Abstract}

Sound, basically characterized as air in motion since ancient Greece, has been at the core of the theories of many philosophers, as well as musicians, poets, scientists, and theologians. Under the auspices of Hellenic thought, Renaissance scholars tried to define what sound is, unveiling its vibrating forces to understand its ability to shake the human body and soul. In such a way, the ever-present metaphors of harmony were much more than mere imagined, unreal thoughts: through them, Renaissance humanists shaped, organized, and understood the structure and passions of the world itself.

\section{Heritage and Rupture with the Tradition}

What is sound? What is its nature? What is its sense? These and other questions about sound have had great relevance in Western thinking since ancient Greece (Barker 1989; Mathiesen 1999; Hagel 2010). We can find eloquent examples of such problematics in writings of many philosophers, from Plato and Aristotle to Church
Fathers like Isidore or Augustine. Writing from his platonic background, Augustine, an author frequently cited and paraphrased during the Middle Ages and the Renaissance, cleverly posed several important issues concerning sound in a brief passage of his Enarrationes in Psalmos: "One who jubilates does not utter words, but it is rather a kind of sound of joy without words; for the voice is thus the soul dispersed out in joy, demonstrating as much as it is able the feeling without grasping the sense" (1990).

Trying to explain what sound is and does, Augustine evokes a dichotomy that will be a recurrent theme throughout the history and philosophy of music: "music" and "words," "sound" and "meaning," in the end (Dillon 2012). In his commentary, the voice has to make words audible (cantus) and unambiguously communicate the meaning of them (res) at the same time: therefore, at the very core of the problem is language. By focusing language's conundrum from a musical standpoint, Augustine articulates the disconcerting tension between both, sense and sound. But we must not overlook that, for him, such a way of singing fully outdoes language, making music an ideal vehicle to feel and communicate with God and, consequently, a field to reflect upon and through it. Later, the finding of a complete copy of Quintilian's Institutio Oratoria by Poggio Bracciolini in 1416 would give new impetus to rethink the conflation of sounds/music with words/sense.

Since the thirteenth century, musical thinking was strongly influenced by ancient texts, due to 
the discovery and study of complete and authoritative testimonies of Greek theory. Well-known humanists like Giovanni Pico della Mirandola or Giorgio Valla collected manuscripts, published translations, and wrote commentaries that molded the understanding of ancient writings. Certainly, one of the figures whose ideas about sound influenced philosophers and musicians over centuries was Pythagoras. His relevance for the study of the subject in general, and particularly for music, resides firstly in his claimed establishment of the numerical base of acoustics. As told by Nicomachus (1994), Pythagoras determined the arithmetic ratios of intervals after listening how hammers of different weights played consonant and dissonant sounds while he was walking near a forge. Secondly, but closely related, are the Pythagorean beliefs in a universe ordered by the same numerical proportions that produce musical harmonies, the so-called music of spheres.

From all the conceptions of sound based in Pythagorean and neo-Pythagorean accounts which Renaissance scholars usually knew, basically through translations made by Latin writers like Boethius (1867) (De Institutione Musica), it is worth noting two Platonic myths that had a longlasting impact: in the first one, the explanation of the creation of the World-Soul is accomplished using Pythagorean proportions (Timaeus). In the myth of Er (Republic), Plato described the universe as a set of concentric rings on the surface of each of which a Siren sits singing (questioned by Aristotle 1995). Together they produce the harmony of spheres, a harmony created by difference, discordia concors (Haar n.d.). Due to the Hellenic inheritance, the concept of sound in the Renaissance was not only "a particular movement of air" (Aristotle 2011) but a way to explain, order, and, ultimately, make sense of the world and the whole universe (Godwin 1987, 1993). Such Pythagorean ideas were constantly reworked by Neoplatonist scholars until the end of the Renaissance.

\section{Innovative and Original Aspects}

Aristotle's sparing definition of sound mentioned above has, nevertheless, two fundamental terms, words repeated time and again when an explanation of sound had to be proposed: air and movement. That fact can be seen perfectly clear in the theoretical works of Marsilio Ficino, one of the Renaissance thinkers most interested in scrutinizing the effects and influence of sound and music on the spirit (Ficino 1959; Tomlinson 1993; Prins 2014). Let me start with air, the first keyword. Integrating Neoplatonism with Aristotelian doctrines, Stoicism with medical thinking, in De vita libri tres, Ficino provides a glimpse of his notion of spirit: "almost not a body but a soul; or again, almost not a soul but a body" (1989). It is, of course, a ghostly image of the spirit, characterized as an airy substance lying in between the incorporeal soul and the corporeal body. It acted as a fundamental nexus, transmitting the vibrant force from the soul to the body and sending the corporeal spurs to the soul. Also in $D e$ vita, Ficino constantly related sounds and music with air or airy vapors and scents. In other words, spirit and sound, sound and spirit, were made of the same substance, so it is easy to grasp why sound and music could move the spirit.

Move. This leads me to the second term: movement, motion. In fact, this issue has been already raised with the air. By acting as connection of the body with the soul (and vice versa), the spirit had to remain in constant movement. Likewise, sound was not only air but air dynamically and lively set in motion. At this point, we should remember Plato's dialogue concerned with the movement of the soul, where he states that mousike and philosophia provide the soul with motion, and when this motion has been properly regularized, it joins high and low sounds resulting in an "imitation of the divine harmony revealed in mortal motions" (Timaeus). Although Plato's theory surely was the basis of Ficino's one, he increased the complexity of the subject. From his perspec-

tive, the movement of music could emulate human gestures, affections, or even the heavens: it was capable to imitate anything. The sound of music, therefore, was not only able to move and to enact passions, but it also had the capacity to mimic the most meaningful and rational motions.

Ficino was by no means the only one who apparently broke with the primacy of the visual in favor of sound and hearing. In a dialogue on the theme of love called Gli asolani, the Italian literary theorist and poet Pietro Bembo, always 
concerned with the sound of the words, praised hearing for being the sense by which we can perceive the beauty of the soul. Persuasion, according to Bembo, was encouraged by an occult force of the words, a power caused by the natural properties of them (Bembo 1961). Ignatius of Loyola could have thought something similar about the power of sounds to persuade (Filippi 2015): meant to be read out loud, the fifth of his Spiritual Exercises encouraged CounterReformation Catholics to meditate about Hell by "hearing wailings, howlings, cries of sinners" to get an "interior sense of the pain which the damned suffer" (Schwartz 2011). "Nihil est sine numero sonoro," Luther dixit (1965).

We have already talked about what sound is and why it could powerfully affect human body and soul. But how could sound produce these effects? I think we have to find the possible answers in music. On the one hand, music treatises from the end of the fifteenth to early seventeenth centuries usually emphasized the correlation of each of the modes (scales formed by a distinctive distribution of their sounds) with a particular ethos (Gaffurius 1492, 1496). Although it was very far from its original conception, such a Greek term generally shows the belief, shared by many Medieval and Renaissance scholars, that music can carry, enact, or even impose a specific mood on human beings. As the Renaissance tradition was by no means systematic, let us see as an example the conception of the third and four modes, Phrygian and Hypophrygian, as established by Spanish theorist Bartolomé Ramos de Pareja (1990). The Phrygian mode, which is associated by Ramos de Pareja with the yellow bile, increases cruelty and anger. By contrast, music composed in the Hypophrygian mode weakens it and so on for each mode, which, in Ramos de Pareja's theory, were also linked to planets, colors, and muses.

On the other hand, we should not forget music's mimetic capacities. Sixteenth-century composers and poets began to explore the wide variety of sympathies existing in between text and music (Zarlino 1573; Montanos 1592; Salinas 1977). In the words of the Spanish music theorist Juan Bermudo: “.. .everything said in the text can be imitated in music... the notes should be put down so, in everything and for everything, they are very much in agreement with the text." As we have seen before, words (as a sonic force) and music had a similar ontological status due to their airy and dynamic nature. So, blending both together would make them an overwhelmingly effective medium not only to reflect things on the imagination, as Giordano Bruno would say, but also to pierce the soul (Bruno 1991).

\section{Impact and Legacy}

As he continued discussing the relations between sound and word, music and rhetoric, in his astonishing Musurgia Universalis (1650), Athanasius Kircher included a plate representing Pythagoras, who looks at the reader while signaling an earshaped forge (Godwin 1979). Inside it, the hardworking blacksmiths are sounding the anvil, the apparently artless object through which the philosopher's thoughts about sound were filtered, ideas that constituted the basis for speculative as well as scientific approaches to the issue during centuries. In Kircher's sonorous thinking survived the Pythagorean ideal of the numerical relations of sounds, the numerus sonorous, an ideal underpinned, as we have seen, by entire generations of musicians and philosophers, from Johannes Tinctoris (Wegman 2005) to Gioseffo Zarlino (1573), from Marsilio Ficino to Robert Fludd.

Although the validity of traditional arithmetic ratios remained apparent and influent, since the second half of the sixteenth century, almost all the great philosophers and scientists of the time devoted empirical attention to the subject of sound (Burnett et al. 1991; Pasnau 2011). For thinkers like Girolamo Fracastoro, G. B. Benedetti, Vincenzo and Galileo Galilei, Johannes Kepler, Francis Bacon, Marin Mersenne, or René Descartes (Descartes 1984; Stephenson 1994), one of the main areas of inquiry was the nature of pitches, precisely the domain where Pythagoras had a major impact. These philosophers displaced the issue from the Pythagorean view to a perspective based on physics (Taylor and Campbell n.d.). 
In this sense, in 1546 Fracastoro argued that pitch depends on the frequency of impulses transmitted through the air, by sequences of alternating condensations and rarefactions that produce a wavelike motion. On the other hand, Benedetti is considered to have been the first to relate the sensations of pitch and consonance to vibration frequencies (1563).

Other examples were the empirical studies of Vincenzo Galilei, father of Galileo, who demonstrated that the simple numerical ratios that constitute the consonant intervals in pipes and string lengths were not valid for the relative weights of hammers nor for the relative volumes of pipes. $\mathrm{He}$ also exposed that, the length of a string held constant, but changing its other parameters, such as tension or material, resulted in alterations in its perceived pitch. Supporting an empirical science of music perception, anticipating many contemporary psychologists, Galilei argued that disputes over tuning systems were futile, since the small differences that are at issue were not perceivable (Taylor and Campbell n.d.).

These studies cemented the way for a new mode of empirical investigation of pitch and sound perception (Erlmann 2010). Following this path, Galileo realized that pitch corresponds to frequency and showed that musical intervals could be uniquely characterized by frequency ratios. In order to demonstrate this fact, Galileo had to do a fundamental shift of perspective, considering not the sound produced by the vibrating object but the sound that reaches the ear. He also made the clearest presentation of the relation between pitch and frequency, elucidating why some intervals are more consonant than others.

However, the empirical study of sound wouldn't have been the same without the figure of Marin Mersenne, whose Harmonie Universelle (1636) is a landmark in the history of the issue. Mersenne, who went so far as to claim that "all movements that occur in the air, in water, or elsewhere, can be called sounds, inasmuch as they lack only sufficiently delicate and subtle ear to hear them," designed an ingenious experimental method by which he demonstrated that the vibration frequency of a string varies inversely with its length. Furthermore, he was able to relate the sensation of pitch to vibration frequency and to estimate the vibration frequency of a particular pitch. Moreover, he was interested in the phenomenon of beats and overtones, anticipated later studies on timbre. These empirical investigations form the basis of later inquiries about sound, such as Newton's mathematical analysis of the propagation of sound or Euler's work on overtones (Newton 1999).

\section{Cross-References}

\author{
Alchemy \\ - Astrology \\ - Astronomy \\ Bruno, Giordano \\ Cosmology \\ Ficino, Marsilio \\ Fludd, Robert \\ Galileo \\ Mathematics \\ Neoplatonism
}

\section{References}

\section{Primary Literature}

Aristotle. 1995. In On the heavens, ed. Stuart Leggatt. Warminster: Aris \& Phillips.

Aristotle. 2011. In De Anima: On the soul, ed. Mark Shiffman. Newburyport: Focus Publishing/R. Pullins Co. Augustine. 1990. In Enarrationes in Psalmos, ed. Eligius Dekkers and Johannes Fraipon. Turhout: Brepols.

Bembo, Pietro. 1961. In Opere in Volgare, ed. Mario Marti. Florence.

Boethius, A. 1867. In De Institutione Musica, in De Institutione Arithmetica Libri Duo de Institutione Musica Libri Quinque Accedit Geometria quae fertur Boetii, ed. Gottfried Friedlein. Leipzig.

Bruno, G. 1991. In On the composition of images, signs \& ideas, ed. Dick Higgins. New York: Willis, Locker \& Owens.

Ramos de Pareja, B. 1482. Musica practica (trans: Moralejo, J.L.). Madrid: Alpuerto. 1990.

Descartes, R. 1984-1991. The philosophical writings of Descartes, 3 vols, ed. J. Cottingham, R. Stoothoff, D. Murdoch, and A. Kenny. Cambridge: Cambridge University Press.

Ficino, M. 1959. In Opera Omnia, ed. M. Mario Sancipriano. Turin: Bottega d'Erasmo.

Ficino, M. 1989. In Three books on life, ed. Carol V. Kaske and John R. Clark. Binghamton: MRTS. 
Gaffurius, F. 1492. Theorica Musicae. Milan: Philippium Mantegatium. http://imslp.org/wiki/Theorica_musicae_ $\% 28$ Gaffurius,_Franchinus\%29.

Gaffurius, F. 1496. Practica Musicae. Milan: Gulielmum signer Rothomagensem. http://imslp.org/wiki/Practica musicae_\%28Gaffurius,_Franchinus\%29.

Kircher, A. 1650. Musurgia Universalis. Rome: Francesco Corbelletti. https://imslp.org/wiki/Musurgia_Universa lis_\%28Kircher,_Athanasius\%29.

Luther, M. 1965. In Luther's works, vol. 53: Liturgy and hymns, ed. Ulrich S. Leopold. Philadelphia: Fortress Press.

Mersenne, M. 1636. Harmonie universelle, contenant la théorie et la pratique de la musique. Paris: Sebastien Cramoisy.

Montanos, F. 1592. Arte de musica theorica y pratica. Valladolid: Diego Fernández de Cordoba. http://bdh. bne.es/bnesearch/biblioteca/Arte\%20de\%20musica,\% 20theorica\%20y\%20practica\%20\%20\%20/qls/Monta nos, $\% 20$ Francisco $\% 20$ de $\% 20 \% 28$ ca. $\% 201528 \% 20$ ca. $\% 201592 \% 29 / \mathrm{ql} / \mathrm{bdh} 0000057630 ;$ jsessionid $=583 \mathrm{E} 2$ 9C31B9F07147CE145D06CFD3089.

Newton, I. 1687/1713/1726. The principia: Mathematical principles of natural philosophy (trans: Cohen, I.B., and Anne Whitman). Berkeley: University of California Press, 1999.

Nicomachus. 1994. In The manual of harmonics of Nicomachus the Pythagorean, ed. Flora R. Levin. Grand Rapids: Phanes Press.

Salinas, F. 1977. De musica libri septem (trans: Ismael Fernández de la Cuesta). Salamanca: Alpuerto, 1977.

Zarlino, Gioseffo. 1573. Institutioni Harmoniche. Venice: De Franceschi. http://imslp.org/wiki/Le_Istitutioni_ Harmoniche_\%28Zarlino,_Gioseffo\%29.

\section{Secondary Literature}

Barker, A., ed. 1989. Greek musical writings: Harmonic and acoustic theory. Cambridge: Cambridge University Press.

Burnett, C., M. Fend, and P. Gouk, eds. 1991. The second sense: studies in hearing and musical judgement from antiquity to the seventeenth century. London: The Warburg Institute.
Dillon, E. 2012. The sense of sound: Musical meaning in France, 1260-1330. Oxford: Oxford University Press.

Erlmann, V. 2010. Reason and resonance: A history of modern Aurality. New York: Zone Books.

Filippi, Daniele. 2015. A sound doctrine: Early modern Jesuits and the singing of the catechism. Early Music History 34: 1-43.

Godwin, J. 1979. Athanasius Kircher: A renaissance man and the quest for knowledge. London: Thames and Hudson.

Godwin, J. 1987. Harmonies of heaven and earth: The spiritual dimensions of music. Rochester: Inner Traditions International.

Godwin, J. 1993. Harmony of the spheres. A sourcebook of the Pythagorean tradition in music. Rochester: Inner Traditions International.

Haar, J. n.d. Music of the spheres. In Grove Music Online. Oxford Music Online. Oxford University Press (Web).

Hagel, S. 2010. Ancient Greek music: A new technical history. Cambridge: Cambridge University Press.

Mathiesen, T. 1999. Apollo's lyre: Greek music and music theory in antiquity and the Middle Ages. Lincoln/London: University of Nebraska Press.

Pasnau, R. 2011. Metaphysical themes, 1274-1671. New York: Oxford University Press.

Prins, J. 2014. Echoes of an invisible world. Marsilio Ficino and Francesco Patrizi on cosmic order and music theory. Leiden: Brill.

Schwartz, H. 2011. Making noise: From Babel to the big bang and beyond. New York: Zone Books.

Stephenson, B. 1994. The music of heavens: Kepler's harmonic astronomy. Princeton: Princeton University Press.

Taylor, C., and M. Campbell. n.d. Sound. In Grove Music Online. Oxford Music Online. Oxford University Press.

Tomlinson, G. 1993. Music in renaissance magic: Toward a historiography of others. Chicago: University of Chicago Press.

Wegman, R. 2005. Johannes Tinctoris and the art of listening. In Studies on Renaissance music in honour of Ignace Bossuyt, ed. Mark Delaere and Pieter Bergé. Leuven: Leuven University Press. 